\title{
Effects of Natural Resource exploitation on CEMAC Countries Development: The Human Capital Channel
}

Ghamsi Deffo Salomon Leroy ${ }^{\uparrow 1}$, Ajoumessi Houmpe Donal ${ }^{1}$, Demgne Pouokam Véronique ${ }^{1}$, Njoupouognigni Moussa Ledoux ${ }^{2}$

${ }^{1}$ Dschang School of Economics and Management, University of Dschang-Cameroon

${ }^{2}$ ENSET Douala, University of Douala-Cameroon

\begin{tabular}{ll}
\hline ARTICLE INFO & ABSTRACT \\
\hline Article History & Purpose: \\
& The aim of this study is to determine the effect of the exploitation of natural resources
\end{tabular}

Received 26 June 2021 Accepted 17 November 2021

JEL Classifications

A 10, C23, C51, O43

Keywords:

Natural Rent, Economic

Development,

Human Capital and Panel data. on the development of CEMAC countries and to examine human capital as a transmission channel.

Design/methodology/approach:

In order to achieve our goal, we formulate a panel of 6 CEMAC countries over the period 2002-2018. This period of study is justified by the surge in the prices of natural resources in the market and also a fall of the prices of basic resources following two large exogenous shocks (subprime crisis and 2015 oil crisis). The estimation method use is the fixe effect, two stage least square and the Maximum likelihood with limited information.

\section{Findings:}

Of the estimation by the fixed-effect method show that natural resources abundance measured by: total rent, oil rent and forest rent has a negative effect on economic development. Likewise, human capital contributes to the transmission of these effects. The minimum education rate beyond which natural resources no longer have a negative effect on economic development, measured by the logarithm of GDP, is approximately $0.52,0.51$ and 0.48 respectively when we consider the total rent, the oil rent and the forest rent. This result is confirmed with the adoption of Maximum likelihood with limited information and the Two Stage Least Squared.

\section{Research limitations/implications:}

This study is limited in time and space. Moreover, the failure to take into account certain human capital or development variables.

Originality/value:

In the literature on the natural resources curse, the analysis of transmission channels in developing countries remains largely unexplored. The human capital component studied in this article is one of the first in the case of CEMAC countries. Also, we studied the effect of many resources, both renewable and non-renewable.

\section{Introduction}

Natural resources are essential for the monitoring of men and the economic development of nations. Several states of the world have used raw materials to increase their levels of development, and are currently using these same resources. In the 1960 s, about $80 \%$ of developing country exports were raw materials, while today $80 \%$ of exported goods are industrial products (Gelb, 2010).

Until the end of the 1980s, economic orthodoxy considered the abundance of natural resources as an important vector of development, which made it possible to attract investors and increase export income (Carbonnier, $2007)$.

${ }^{\dagger}$ Corresponding Author: GHAMSI DEFFO Salomon Leroy

Email: lavoidef@gmail.com 
However, during the 1970s, the rise in the price of hydrocarbons had negative consequences on the world economy. There had been a decline in growth, a slowdown in industrial production, rising unemployment and worsening budget deficits. This fact was recognized as the first oil shock.

After the oil shock in 1973, a debate on the risk of depletion of natural resources arose in the economic literature at the end of the 1970s. An intergenerational allocation of resources held the attention of researchers. Hartwick (1977) discusses the idea of substitution of different forms of capital. For example, natural resources that have been completed depleted may be replaced by artificial capital (Noula and al., 2020).

The rise in oil prices at the end of the 1970s again plunged the world's economies into a chaotic situation, similar to that of 1973: it was the second oil shock of 1979.

A year later, the exploitation of natural resources, more precisely petroleum, was still considered a lever for economic development. After the shock of 1986 set up by the Organization of the Petroleum Exporting Countries (OPEC), researchers are interested in the role of natural resources in economic development. It was then that in 1993 the concept of the natural resource curse was introduced into the literature by Auty (1993). Indeed, he notes that States rich in natural resources are less developed than those poor in basic resources. The work of Sachs and Warner (1995) opened a wide debate on the relationship between the exploitation of natural resources and economic development. Indeed, show that most countries that have an economy dependent on natural resources have had slower economic growth.

In addition, natural resource-dependent economies are increasingly exposed to exogenous shocks. After the shocks of the 1970 s which considerably affected the world economy, the CEMAC countries were particularly affected by the economic crises of 2008 and 2015.

About the 2008 financial crisis, the financial policy of the United States of America was the main cause of the outbreak of this economic depression which very quickly affected all of the world's economic circuits.

CEMAC countries have particularly suffered. The financial and economic crisis of 2008 affected the main levers of growth in African countries. The demand and prices of African raw materials have fallen; promises of increased official development assistance made by developed countries have not been fulfilled (Noula and al., 2020; AfDB, 2009).

The second crisis is that of 2015. Indeed, after having fluctuated for several years between 80 and 110 US dollars, the price of a barrel of crude oil began to fall in the second half of 2014. A slight rise was observed in the spring of 2015, passing thus at the US \$ 60 per barrel, a rise mainly due to the seasonal increase in American demand (the "driving season" from April to September), during which Americans massively use their vehicles to travel. Prices fell further at the end of the summer (Noula and al., 2020). WTI ${ }^{2}$ (West Texas Intermediate) fell below the US $\$ 40$ per barrel at the end of August 2015. It stood at the US $\$ 45$ per barrel on September 9, 2015 (DGRIS, 2015; Noula and al., 2020).

This crisis also confirms the vulnerability of the CEMAC countries to external shocks and the economic turmoil of the countries of this economic and monetary community. The economic vulnerability of the countries of this community is seen through the growth of the GDP.

After the 2015 crisis, GDP growth remained very low, compared to that of some economic zones and that of the world (Noula and al., 2020).

Table 1: GDP growth of some economic zones and that of the world

\begin{tabular}{|l|c|c|c|c|}
\hline & 2014 & 2015 & 2016 & 2017 \\
\hline Monde & 3.6 & 3.5 & 3.2 & 3.7 \\
\hline ASS & 5.1 & 3.4 & 1.5 & 2.8 \\
\hline Zone franc & 5.5 & 4.3 & 3.6 & $\mathbf{0 . 0 3}$ \\
\hline CEMAC & $\mathbf{4 . 6}$ & $\mathbf{1 . 9}$ & $\mathbf{0 . 2 3}$ & 6.7 \\
\hline UEMAO & 6.5 & 6.3 & 2.5 & 3.0 \\
\hline Comores & 2.1 & 1.0 & 2.1 & $\mathbf{0 . 0 3}$ \\
\hline
\end{tabular}

Source : Ghamsi et al. (2020)

\footnotetext{
${ }^{1}$ During the holiday period, there is an increase in the use of means of transport and consequently an increase in fuel consumption.
} 
In 2014, before the outbreak of the crisis, the growth of CEMAC was 4.6, very close to the growth of economic zones like ASS and the franc zone. It was even superior to that of the world and Comoros. In 2015, the year the crisis started, CEMAC's GDP growth fell from 4.6 to 1.9, lower than that of the world, WAEMU and the Franc zone. In 2016, this growth continued to drop from 1.9 to -0.23 , lower than that of all the economic zones mentioned in Table 2. The same is true for 2017, where we observed a slight increase in growth (from -0.23 to 0.03); but which was also the weakest among the aforementioned economic zones.

In addition, the CEMAC States are classified among the least developed on the planet. According to UNDP (2018) the most developed CEMAC country after the crisis in 2015 was Gabon with an HDI of 0.702, but the latter is only ranked 110th in the world. Gabon is followed by Congo with an HDI of 0.606 and is ranked 137 th in the world. Two CEMAC countries namely Chad and CAR are among the top 5 least developed countries on the planet with development indicators of 0.404 and 0.367 respectively. These countries are ranked 186 th and 188 th in the world rankings (Noula and al., 2020).

In addition, the literacy rate of Central Africans aged 15 to 24 was less than $40 \%$ in 2015 , or about $48 \%$ for men and $27.0 \%$ for women. This secondary school enrollment rate was only around 13\% in 2012. Girls are clearly at a disadvantage compared to boys, as the secondary school enrollment rate for the latter was $17.93 \%$ in 2012, which is close to double that of girls, which $9.34 \%$ (UN, 2016) was.

This economic and social unrest in countries dependent on natural resources is known in the literature as the "resource curse". The work of Sachs and Warner $(1995,1997)$ broadened the debates on the relationship between natural resources and economic development. Because, the latter explain the phenomenon of the curse of natural resources by the theory of the Dutch Syndrome, or the "booming sector". According to this theory, the exploitation of an important resource in a country results in the destabilization of the productive system (Gregory, 1976; Corden, 1984; Corden and Neary, 1982).

An important question in the economic literature is what the transmission channels of the natural resource curse are. First, the poor quality of institutions (Phillippot, 2009; Torvik, 2002; Mehlum et al., 2006; Aoun, 2008), institutions occupy an important place in economic analysis, and constitute the explanatory basis for several economic failures (Acemoglu et al., 2001).

According to Philippot (2009), the exploitation of natural resources leads to the sectoral distortion of the national economy; second, it negatively affects the quality of institutions. Likewise, Institutions create conditions conducive to the 'voracity effect', highlighted by Lane and Tornell (1999), which show that revenues from the exploitation of natural resources are diverted by an elite group towards less profitable projects.

Second, the volatility of commodity prices (Shaxson, 2005; Van der Ploeg and Ploelhekke, 2008; Avom and Carmignani, 2009).

Volatility leads to poor economic planning, leading to a budget deficit which pushes states into debt. Countries whose economies are based on the exploitation of natural resources tend to get into debt, because it presents guarantees of solvency in financial markets (Noula and al., 2020).

Third; a deficit in human capital indeed: human capital is an important determinant of economic development. It has been recognized as such on the theoretical and empirical level by the work of Romer (1986), Lucas (1988) and Mankiw et al. (1992). Indeed, Mankiw et al. (1992) shows that the introduction of human capital in the neoclassical model of Solow (1956), will give robust results (Gurgand 2002).

Likewise, human capital, more precisely education, stimulates growth and improves living conditions through several chains: firstly, by increasing the efficiency of the labor force, secondly by creating conditions of good governance and thirdly, by improving health care offerings (Ghamsi and Tadadjeu, 2020).

Moreover, According to Birdsall et al. (2001), Gylfason (2001), Stjins (2006), Coulibaly (2013), Kim and Lin (2017), Behbudi et al. (2010), Shao and Yang (2014), Manning (2004), the exploitation of natural resources negatively affects human capital.

Zallé (2018), suggest that countries must simultaneously step up their investments in human capital to turn the natural resource curse into a blessing.

Likewise, for Hua-Ping (2018) Governments should use revenues from natural resource exploitation to increase investment in education to improve human capital.

Human capital promotes workforce growth, innovation and creativity, encourages people to get involved in political life, to seek good governance through democracy. Human capital also facilitates the absorption of superior technologies from developed countries (Barro, 2001). Education positively affects health and helps reduce inequalities (Aghion et al. 1998).

Likewise, Ghamsi et al. (2019) Believe that the exploitation of mineral resources reduces the human capital of CEMAC countries. Indeed, their study reveals that the exploitation of mineral resources negatively affects education, reduces life expectancy and increases infant mortality.

The countries of the CEMAC zone have made considerable efforts in education over the past two decades; those despite the resurgence of conflicts that force populations to move. However, Gylfason (2001); Birsal et al (2001), Atangana (2019), found that, the problem of African countries rich in natural resources is the low rate of education; hence the controversy which raises the question of knowing: does education allow natural resources to boost or harm economic development of African countries? Specifically, this article is about verifying the level of education from which natural resources exploitation boosts economic growth. 
Our objective is to determine on the one first the effect of the exploitation of natural resources on the economic development of the CEMAC countries; and second to analyze the contribution of human capital in the transmission of these effects. The remainder of this article is organized as follows: section 2 is devoted to the literature review, section 3 is reserved for the methodology and presentation of the results and section 4 is for the conclusion.

\section{Natural resources and education: the teachings of literature}

A big debate in the natural resource curse literature is the link between human capital and natural resource and the economic development of commodity-dependent countries (Gylfason, 2001; Coulibaly, 2013; Stjins, 2006; Kim and Lin, 2017; Behbudi and al., 2010; Ghamsi and al., 2020; Manning, 2004).

According to Shao and Yang (2014) countries exposed to the natural resource curse are those with low investments in human capital. They also show that the government, through the institutions it embodies, can improve the quality of education by developing a job offer for a skilled worker. Atangana (2019) seems to agree because according to him, governments of African countries must adopt good institutions to allow natural rents to participate in the accumulation of human capital.

In most countries of the world, the benefits of education are exhibited, but investment in the education sector is hampered by a lack of financial means in most countries (Ghamsi and al., 2019). However, the abundance of natural resources can increase investments in human capital in countries. In contrast, countries rich in natural resources are countries that invest very little in education, compared to other countries. Investing in human capital can create a virtuous circle. But, the governments of the countries rich in NR are pushing the whole population to move away from this virtuous circle. (Ghamsi and al., 2019; Birdsall et al., 2001).

Similarly, the study by Gylfason (2001) and Ghamsi and al. (2019), shows that education is the cause of poor economic performance in countries rich in natural resources. In his opening remarks, he recalled that countries endowed with natural resources had low long-term economic growth, compared to countries endowed with natural resources. This is the case of Nigeria which, after independence in 1960, and although rich in petroleum resources, has a per capita GNP not very different from that of countries poor in natural resources. Several other countries are in the same situation, notably Venezuela, Kuwait, Libya, Qatar, etc.

Gylfason (2001) and Ghamsi and al. (2019), shows that among the 65 countries rich in natural resources, four stood out for their domestic investment, their rate of investment and their rate of GNP growth. Among these countries we can cite Botswana, Indonesia, Malaysia and Thailand. The three Asian countries have achieved their success by diversifying and industrializing their economies. And Botswana, rich in diamonds, is in the same vein.

In his analysis, Gylfason envisions 4 channels of transmission of the natural resource curse: firstly, the theory of Dutch syndrome; a boom in the natural resources sector is accompanied by an increase in the exchange rate and subsequently, induces a decline in exports in the manufacturing sector. Secondly, the rentseeking behavior. Thirdly, the quality of institutions and finally, education.

In contrast, Bravo-Ortega and De Gregorio (2005) highlight two main reasons explaining the negative effect of natural resources on growth and economic development. The quality of institutions. Institutions create conditions favorable to the "voracity effect" indeed, the "voracity effect": highlights the fact that in states endowed with bad institutions, the elite in power tends to err on the side of optimism by initiating gigantic projects, when it does not simply divert the rent for its account or in a purely clientelist logic (Carbonnier, 2007).

Second, the misallocation of resources between various activities having different effects on growth. For example, financial, human and material resources in a country can be allocated either in the extractive sector or in the production of human capital. The main results of their analysis show that growth in an economy is a weighted average of the growth of the natural resources sector and that of the industrial sector. Indeed they lead to the hypothesis according to which natural resources use a constant amount of human capital stock unlike the industrial sector which uses ever-increasing human capital and generates rapid economic growth. The exploitation of natural resources limits growth as long as the level of human capital is low. Zallé (2018), suggest that countries must simultaneously step up their investments in human capital and struggle to turn the curse of natural resources into a blessing; it is important to combine one form of capital with another. The transformation of natural capital into human capital can be a means of increasing total output if this conversion aims at more productive forms of capital (OECD, 2009).

Likewise, Behbubi et al. (2010) start from the observation that studies of the relationship between growth and abundant exploitation of NRs (Natural Resources), are mixed because some of the natural resources seem to be the engine of economic growth; but for them, it does not seem easy to achieve development by exploiting only these resources (Ghamsi and al., 2019). However, economic theory suggests that all other things being equal, natural resources increase the possibilities of a powerless economy, as well as economic growth, but the exploitation of natural resources has become rather a curse because, in the long run it harm on economic growth through several transmission channels (Ghamsi and al., 2019). 
Coulibaly (2013) undertakes a study to examine the relationships between the abundance of NRs (Natural Resources), HC (Human capita), and income level in sub-Saharan Africa. Furthermore, he studies the longterm relationship between the abundance of $\mathrm{NR}, \mathrm{HC}$ and income level in the Malian context.

The data used during their study are those of the WB ranging from 1980 to 2012. In Mali, natural resources have a positive effect on human capital in the long term; on the other hand, they harm long-term economic growth, if public expenditure on education is used as a measure of human capital (Ghamsi and al., 2019); and as an abundance of natural resources, the Sachs and Warner measure (export of primary products to GDP).

As for Kim and Lin (2017), they test whether dependence on NRs (Natural Resources) affects investment in human capital. Two indicators of this capital are studied; first, education, and second, health. The results show that dependence on natural resources increases education but decreases health; unlike the exploitation of nonagricultural natural resources which increases education and health.

Gregorio (2005) who focus their attention on institutions and human capital, Kurtz and Brooks (2011), introduce the role of globalization in addition to that of human capital.

According to Kurtz and Brooks (2011), an important question is attracting more and more researchers, that of knowing not why, or how, the exploitation of natural resources, in general, becomes a curse, but rather when the exploitation of said resources becomes. The researchers who took the first approach (namely why, and how), paid less attention to the role of globalization in general and more particularly to the integration in the analysis of the role of the market as a determining factor of the effect of the exploitation of natural resources on growth.

In some developing countries, the naturals resources negatively affect human capital. Indeed, the studies by Ghamsi et al. (2019) have shown that in CEMAC the exploitation of mineral resources (minerals and oil) reduces human capital because it is the source of conflicts of wars which destroys hospitals and schools, displacement of populations to refugee camps, thus abandoning the path to classes.

Note also that, Kurtz and Brooks (2011), also recall that human capital is not a gift from heaven that is granted to some countries and is not granted to others. Both human capital and natural resources must be maintained, oriented towards productive activities that contribute to growth and development. The positive or negative effect of the exploitation of natural resources on economic growth depends particularly on the accumulation of human capital in a society

\section{Methodology and results of the analysis}

Our study is carried out in the CEMAC zone. This economic zone has an area of approximately 30,195,595 km2. The CEMAC zone has six countries namely Cameroon, Congo, Gabon, Equatorial Guinea, Central African Republic (RCA) and Chad. The study takes place from 2002 to 2018. The Period during which we observed a surge in the prices of resources on the market, but also a fall in prices following the crises of 2008 (subprime crisis) and 2015 (oil crisis).

\subsection{Model and Data}

\subsubsection{Theoretical model}

Our basic model is inspired by Mankiw et al (1992) who relate output to natural resources. It is defined as follows:

$$
\left.\mathrm{Y}(\mathrm{t})=\mathrm{K}(\mathrm{t})^{\alpha} \mathrm{H}(\mathrm{t})^{\beta}(\mathrm{HN}(\mathrm{t})) \mathrm{L}(\mathrm{t})^{\Theta} \mathrm{R}(\mathrm{t})\right)^{1^{\alpha} \alpha_{-} \beta_{-} \Theta}
$$

Where $\mathrm{Y}$ stand for production, $\mathrm{H}$ human capital, $\mathrm{R}$ natural resources, $\mathrm{K}$ physical capital stock, $\mathrm{L}$ number of workers and $\mathrm{N}$ population growth.

NH assumes that producers must spend part of the natural rent to increase their human capital.

Let us assume: $\mathrm{y}=\mathrm{Y} / \mathrm{L}, \mathrm{k}=\mathrm{K} / \mathrm{L}$ and $\mathrm{h}=\mathrm{H} / \mathrm{L}$ and $\mathrm{r}=\mathrm{R} / \mathrm{L}$ respectively income, physical capital stock, human capital and rent per head.

$$
k^{\prime}(t)=s_{k} y(t)-(n-g-\delta) k(t)
$$

$$
h^{\prime}(t)=s_{h} y(t)-(n-g-\delta) h(t)
$$

sk savings, sh*n the growth rate of $\mathrm{L}, \mathrm{g}$ the growth rate of natural rent, and $\delta$ the depreciation rate of physical capital.

It is also assumed that human capital depreciates at the same rate as physical capital $\alpha+\beta<1$ which induces a decreasing return to scale. On the other hand, resources are assumed to be exhaustible.

Let us now study the equilibrium of the model:

In the steady state,

$$
\begin{aligned}
& \mathrm{k}^{*}=\left(\frac{s_{\mathrm{k}}^{1-\beta} s_{h}^{\beta}}{n+g+\delta}\right)^{1 / 1_{1} \alpha_{-} \beta_{-} \Theta} \\
& \left.\mathrm{h}^{*}=\left(\frac{s_{\mathrm{k}}^{1-\alpha} s_{h}^{\alpha}}{n+g+\delta}\right)\right)^{1 / 1_{-}{ }_{-} \beta_{-} \Theta}
\end{aligned}
$$


Substituting equation (2) into the production function and considering the logarithm of per capita values, we have :

$\ln \left(\frac{Y(t)}{L(t)}\right)=\ln \mathrm{NH}+\mathrm{gt}-\frac{\alpha+\beta+\theta}{1-\alpha-\beta-\theta} \ln (\mathrm{n}+\mathrm{g}+\delta)+\frac{\alpha}{1-\alpha-\beta-\theta} \ln \left(\mathrm{s}_{\mathrm{k}}\right)+\frac{\beta}{1-\alpha-\beta-\theta} \ln \left(\mathrm{s}_{\mathrm{h}}\right)+\frac{\Theta}{1-\alpha-\beta-\theta} \ln (r)$

\subsection{Empirical model}

To determine the effect of natural resource exploitation on the contribution of human capital to the development of CEMAC countries, we compiled secondary data from three databases: WDI from 2020, WGI from 2020, and the UNDP website.

To determine the effect of natural resource exploitation on the contribution of human capital to the development of CEMAC countries, we compiled secondary data from three databases: WDI from 2020, WGI from 2020, and the UNDP website.

The basic model is of the following form

$$
{\log G D P_{i t}}_{i t} a_{0}+\alpha \operatorname{Rent}_{i t}+\lambda \operatorname{Rent} * \operatorname{Eud}_{i t}+\beta E d u c_{i t}+\mu Z_{i t}+v_{i}+u_{t}+E_{i t}
$$

$\log (G D P)$ : the logarithm of GDP at purchasing power parity (PPP). GDP is the sum of the gross value added by all resident producers in the economy, plus taxes on products and fewer subsidies not included in the value of products. It is calculated without deducting the depreciation of neither manufactured assets, nor the depletion and degradation of natural resources. Data are in current US dollars (Ghamsi and al., 2019).

Rent: this is the measure of the abundance of natural resources. We will use three alternative measures of natural resource abundance; namely, the total resource rent, oil rent and forest rent. The total natural resource rent is the sum of oil rents, natural gas rents, coal rents, mining rents and forest rents.

$E d u c$ : this is the enrollment rate for education. It measures the proportion of a country's population that is in school or the proportion of the population that has attended primary, secondary or higher school (Ghamsi and al.,2019).

Rent $*$ educ: (interaction): this is the linear combination between the variables natural rent and education. It will allow us to analyze the contribution of education in the transmission of the effects of natural rent on the economic development of the CEMAC countries.

$\mathrm{Z}$ represents the matrix of control variables it is made up of:

- Economic openness (open): Generally, openness is measured by the ratio of exports and imports to GDP.

- Government expenditure (govt): Government final consumption expenditure includes all general government current expenditure on purchases of goods and services (including compensation of employees). It also includes most national defense and security spending, but excludes government military spending that is part of government capital formation.

-voice: it reflects perceptions of the extent to which the citizens of a country can participate in the choice of their rulers as well as of freedom of expression, association and freedom of the media.

- Employer (employee): Employers are workers who, working for their own account or with one or more partners, hold the type of jobs defined as "independent jobs", that is to say jobs where the remuneration depends directly on the profits from the goods and services produced and as such, have continuously hired one or more people to work for them as employees -

invest: this is the investment made by the public authorities and the private sector. This variable includes land improvements, factories, machinery and equipment purchases, construction of roads, railways, schools, offices, hospitals, private residential dwellings, and commercial and industrial buildings. Therefore simply modify the value of the constant $\mathrm{a}_{0}$ according to the values of $\mathrm{i}$ and $\mathrm{t}$.

Variable

Natural rent

Employment

Investment

Gross domestic product

Voice and accountability

Education

Government consumption

Source: Author's computation

Table 2: Descriptive Statistics
Abreviation

$\begin{array}{lc}\text { Rent } & \text { WDI (2018) } \\ \text { Employer } & \text { WDI (2018) } \\ \text { Invest } & \text { WDI (2018) } \\ \text { GDP } & \text { WDI (2018) } \\ \text { Voice } & \text { WGI (2018) } \\ \text { Educ } & \text { UNDP (2018) } \\ \text { Govt } & \text { WDI (2018) }\end{array}$

Variable Obs

Obs

Mean

Std. Dev.

Min

Max 


\begin{tabular}{|c|c|c|c|c|c|}
\hline Rent & 90 & 20.048 & 17.713 & $\mathrm{O}$ & 57.452 \\
\hline Govt & 90 & 20.557 & 1.151 & 18.422 & 22.169 \\
\hline Employer & 90 & 4.56 & 4.409 & .12 & 13.027 \\
\hline voice & 90 & -.948 & .85 & -2 & 1.159 \\
\hline GDP & 90 & $2.518 \mathrm{e}+10$ & $1.824 \mathrm{e}+10$ & $2.606 \mathrm{e}+09$ & $8.460 \mathrm{e}+10$ \\
\hline Educ & 90 & .42 & .121 & .198 & .621 \\
\hline Open & 90 & .946 & 1.498 & .043 & 7.218 \\
\hline Invest & 90 & 26.902 & 15.103 & 6.405 & 114.725 \\
\hline
\end{tabular}

\subsection{Results}

Table 3 below shows the results of the regression of equation (1). The measure of natural resource abundance is the total rent of natural resources (total_rent).

The first column of this table presents the regression by the fixed effects method. In this column, the results show us that the natural rent negatively and significantly affects the logarithm of GDP at the $1 \%$ threshold. Any increase in the natural rent of $10 \%$ has the effect of reducing production by approximately $0.28 \%$. This result confirms the theory of Dutch disease, the theory according to which the exploitation of an important natural resource results in a disarticulation of the national productive system which will also result in a decrease in production.

Table 3: Contribution of human capital in the transmission of natural rent effects to the economic development of CEMAC countries

\begin{tabular}{|c|c|c|c|}
\hline VARIABLES & $\begin{array}{l}(\mathrm{FE}) \\
\log \mathrm{GDP}\end{array}$ & $\begin{array}{l}\text { (DMC) } \\
\operatorname{logGDP}\end{array}$ & $\begin{array}{l}\text { (LIML) } \\
\text { LogGDP }\end{array}$ \\
\hline Total_rent & $\begin{array}{l}-0.0280 * * * \\
(0.00571)\end{array}$ & $\begin{array}{l}-0.0640^{* * * *} \\
(0.0172)\end{array}$ & $\begin{array}{l}-0.0689 * * * \\
(0.0189)\end{array}$ \\
\hline interaction 1 & $\begin{array}{l}0.0524 * * * \\
(0.0126)\end{array}$ & $\begin{array}{l}0.122^{* * * *} \\
(0.0355)\end{array}$ & $\begin{array}{l}\text { O.132*** } \\
(0.0391)\end{array}$ \\
\hline Education & $\begin{array}{l}1.010^{*} \\
(0.535)\end{array}$ & $\begin{array}{l}0.183 \\
(0.861)\end{array}$ & $\begin{array}{l}0.0220 \\
(0.920)\end{array}$ \\
\hline Trade & $\begin{array}{l}0.112 \\
(0.0732)\end{array}$ & $\begin{array}{l}0.0804 \\
(0.0899)\end{array}$ & $\begin{array}{l}0.0757 \\
(0.0940)\end{array}$ \\
\hline Employment & $\begin{array}{l}0.441^{* * * *} \\
(0.0666)\end{array}$ & $\begin{array}{l}0.455 * * * \\
(0.0801)\end{array}$ & $\begin{array}{l}0.457^{* * *} * \\
(0.0836)\end{array}$ \\
\hline GFCF & $\begin{array}{l}-0.00594 * * * \\
(0.00204)\end{array}$ & $\begin{array}{l}-0.0107 * * * \\
(0.00321)\end{array}$ & $\begin{array}{l}-0.0113^{* * * *} \\
(0.00342)\end{array}$ \\
\hline G & $\begin{array}{l}-0.0168^{* * * *} \\
(0.00518)\end{array}$ & $\begin{array}{l}-0.0296 * * * \\
(0.00781)\end{array}$ & $\begin{array}{l}-0.0304 * * * \\
(0.00821)\end{array}$ \\
\hline Voice & $\begin{array}{l}-0.537 * * * \\
(0.164)\end{array}$ & $\begin{array}{l}-0.693^{* * *} \\
(0.202)\end{array}$ & $\begin{array}{l}-0.700^{* * * *} \\
(0.211)\end{array}$ \\
\hline Constant & $\begin{array}{l}21.81^{* * * *} \\
(0.269)\end{array}$ & & \\
\hline Observations & 102 & 90 & 90 \\
\hline R-squared & 0.748 & 0.658 & 0.628 \\
\hline Number of country & 6 & 6 & 6 \\
\hline Sargan(p-value) & & 0.179 & 0.187 \\
\hline
\end{tabular}

Source: Author's using Statat 13

Note: Robust standard errors are reported in brackets. (***, **, *) indicate statistically significance at $1 \%, 5 \%$ and $10 \%$.

The results of this regression also show us that education has positive and significant effects at the $10 \%$ level on production. Any increase in the enrollment rate of 1 unit results in an increase in domestic production by about 1.01 units. This result is consistent with the theory of human capital. Indeed, the theoretical model of Mankiw et al. (1992) had shown that the introduction of human capital into Solow's neoclassical growth model (1956) made the model more robust.

To analyze the role of human capital in the transmission of the effects of the exploitation of natural resources on the economic development of CEMAC countries, we constructed the interaction 1 variable (rent_total * education). This variable has a positive and significant effect at the $1 \%$ level on the logPIB. The effect on economic development of a marginal increase in natural rent can be written as follows. 


$$
\frac{\text { dlogGDP }}{\text { drent_total }}=-0,0280+0,0524 \text { Education }
$$

At the optimum, this marginal production of the rent is zero, which implies that:

$$
0,0524 \text { Education }=0,0280
$$

Education $=0,5343$

We, therefore, show that the negative effect of natural rent on economic development is weaker as the education of populations is high. For CEMAC countries that have a high level of education (above 0.5343), the natural resource curse does not apply. In other words, 0.5343 is considered to be the threshold for the enrollment rate in the CEMAC beyond which the curse is not possible.

Education allows the population to better participate in the management of income derived from the exploitation of natural resources. This management can be manifested either by directing the rent towards the productive sectors or by the choice of their representative in state institutions.

On the other hand, investment harms production. This is because the investment is oriented towards sectors exposed to international competition. However, according to Corden (1986), following the exploitation of NRs and the appearance of a large stock of monetary resources in the economic circuit, populations will choose to consume foreign products. This will result in reduced investments but also reduced production.

The number of independent employers contributes to economic development. Employers create added value and fight against unemployment.

Institutions measured by freedoms and responsibilities have negative effects on the logarithm of GDP. In other words, the manifestation of freedoms and responsibilities in CEMAC leads to a decline in economic development in CEMAC.

Government spending negatively affects economic development in CEMAC. Indeed, we observe in CEMAC a good part of the state budget is embezzled by officials and members of the government. This is by false invoicing, overbilling and the realization of fictitious projects.

The second column presents the estimation of equation (1) by the 2SLS. We take into account the criticism formulated by Van der Ploeg and Ploelhekke (2008) which states that the natural rent variable is as endogenous as the resource intensity variable (export / GDP) of Sachs and Warner (1995, 1997).

To correct the endogenous problem, it is imperative to use the assumed endogenous variable. The choice of endogenous variables such as employment in the agricultural sector and the rate of $\mathrm{CO} 2$ (carbon dioxide) emissions is explained by the need to over-identify the model.

The 2SLS regressions and the limited-information maximum likelihood confirm that of the fixed effects, with relatively equal coefficients. In the second column, the natural rent negatively and significantly affects production at the threshold of $1 \%$. An increase of one unit of rent increases gross domestic production by about 0.06 units.

The positive effect of human capital on economic development is not robust as there is no significant relationship between education and $\log ($ GDP $)$ in the second and third columns.

On the other hand, the interaction variable retains its sign and its significance. The threshold for the school attendance rate beyond which the natural rent no longer harm economic development is 0.5245 in the regression by the 2 SLS method and 0.5219 by the limited-information maximum likelihood method (LIML).

Likewise, in the 2SLS and LIML regression employment has positive and significant effects on economic development as does the fixed effects regression, with roughly equal coefficients.

Similarly, we observe that the institutional variable capturing freedom and responsibility in the CEMAC (voice), State expenditure (Govt) and investment (invest) have negative and significant effects on the logarithm of GDP $(\log G D P)$, confirming the regression by the fixed effects method.

In addition, the probabilities of the Sargan statistic are greater than $10 \%$. We cannot reject the null hypothesis of the validity of the instruments.

\subsection{Robustness}

To test the robustness of our results, we used as a measure of the abundance of natural resources other types of resources, namely oil and forest rent.

\subsubsection{Effect of the oil rent on the economic development of CEMAC countries}

Table 4: Contribution of human capital in the transmission of oil rent effects to the economic development of CEMAC countries

\begin{tabular}{llll}
\hline VARIABLES & $\begin{array}{l}(\mathrm{FE}) \\
\operatorname{logGDP}\end{array}$ & $\begin{array}{l}\text { (DMC) } \\
\operatorname{logGDP}\end{array}$ & $\begin{array}{l}\text { (LIML) } \\
\text { LogGDP }\end{array}$ \\
\hline oil_rent & $-0.0212^{* * * *}$ & $-0.0659^{* * * *}$ & $-0.0747^{* * * *}$
\end{tabular}




\begin{tabular}{|c|c|c|c|}
\hline & $(0.00543)$ & $(0.0207)$ & $(0.0244)$ \\
\hline \multirow[t]{2}{*}{ interaction 2} & O.0394**** & $0.127^{*} * * *$ & O. $145^{* * * *}$ \\
\hline & $(0.0122)$ & $(0.0432)$ & $(0.0508)$ \\
\hline \multirow[t]{2}{*}{ Education } & 1.517 **** & 1.062 & 0.902 \\
\hline & $(0.528)$ & $(0.835)$ & $(0.924)$ \\
\hline \multirow[t]{2}{*}{ Trade } & 0.103 & 0.0389 & 0.0272 \\
\hline & $(0.0737)$ & $(0.102)$ & $(0.112)$ \\
\hline \multirow[t]{2}{*}{ Employment } & 0.416 $6^{* * *}$ & $0.400^{*} * * *$ & O.397**** \\
\hline & $(0.0691)$ & $(0.0915)$ & (0.0996) \\
\hline \multirow[t]{2}{*}{ GFCF } & $-0.00559^{* * *}$ & $-0.0121^{* * * *}$ & $-0.0132^{* * * *}$ \\
\hline & $(0.00212)$ & $(0.00398)$ & $(0.00450)$ \\
\hline \multirow[t]{2}{*}{ G } & $-0.0172^{*} * *$ & $-0.0343^{* * * *}$ & $-0.0362^{* * * *}$ \\
\hline & $(0.00570)$ & $(0.00987)$ & $(0.0109)$ \\
\hline \multirow[t]{2}{*}{ Voice } & $-0.563^{* * * *}$ & $-0.788^{* * * *}$ & $-0.810^{* * * *}$ \\
\hline & $(0.171)$ & $(0.237)$ & $(0.259)$ \\
\hline \multirow[t]{2}{*}{ Constant } & $21.58^{* * * *}$ & & \\
\hline & $(0.268)$ & & \\
\hline Observations & 102 & 90 & 90 \\
\hline R-squared & 0.727 & 0.552 & 0.470 \\
\hline Number of countries & 6 & 6 & 6 \\
\hline Sargan(p-value) & & 0.162 & 0.179 \\
\hline
\end{tabular}

Source: Author's using Statat 13

Note: Robust standard errors are reported in brackets. (***, **, *) indicate statistically significance at $1 \%, 5 \%$ and $10 \%$

In Table 4 above, the measure of natural resource abundance is oil rent. As in Table 3 , the oil rent negatively affects economic development in CEMAC. Education has positive effects on log (GDP); but, this result is not robust.

To determine the role of human capital in the transmission of the effects of the exploitation of natural resources on economic development in CEMAC, we constructed the variable interaction2 (education * oil_rent). This variable has a positive effect on the logarithm of GDP in all of our regressions.

Similarly, education contributes positively to the transmission of the effects of the oil rent to economic development, the level of education contributing to the transmission of the effects is appreciably equal to that resulting from table $\mathrm{N}^{\circ}$ (0.538 by the method fixed effects, 0.5188 by 2 SLS 0.5151 by LIML method).

\subsubsection{Effect of forest rent on the economic development of CEMAC countries}

Table 5 below shows the results of the regression, taking the forest rent as a measure of the abundance of natural resources.

Table 5: Contribution of human capital in the transmission of forest rent effects to the economic development of CEMAC countries

\begin{tabular}{|c|c|c|c|}
\hline & $(\mathrm{FE})$ & (DMC) & (LIML) \\
\hline VARIABLES & $\log \mathrm{GDP}$ & $\log \mathrm{GDP}$ & LogGDP \\
\hline \multirow[t]{2}{*}{ Forest_Rent } & $-0.0970^{* * * *}$ & $-0.799^{*}$ & $-0.917^{*}$ \\
\hline & $(0.0327)$ & $(0.432)$ & $(0.534)$ \\
\hline \multirow[t]{2}{*}{ interaction3 } & $0.158 * *$ & $1.631^{*}$ & $1.875^{*}$ \\
\hline & $(0.0723)$ & $(0.902)$ & $(1.116)$ \\
\hline \multirow[t]{2}{*}{ Education } & $1.314^{* *}$ & -6.748 & -8.103 \\
\hline & $(0.633)$ & $(5.175)$ & $(6.369)$ \\
\hline \multirow[t]{2}{*}{ Trade } & 0.0365 & 0.0739 & 0.0755 \\
\hline & $(0.0773)$ & $(0.196)$ & $(0.225)$ \\
\hline \multirow[t]{2}{*}{ Employment } & $0.475^{* * *}$ & $0.572^{* * *} *$ & $0.588^{* *}$ \\
\hline & $(0.0757)$ & (0.198) & (0.229) \\
\hline \multirow[t]{2}{*}{ GFCF } & -0.00165 & 0.0109 & 0.0128 \\
\hline & $(0.00227)$ & $(0.00922)$ & $(0.0111)$ \\
\hline
\end{tabular}




\begin{tabular}{llll} 
G & -0.00527 & 0.0299 & 0.0360 \\
& $(0.00476)$ & $(0.0256)$ & $(0.0311)$ \\
Voice & $-0.404^{* *}$ & 0.607 & 0.782 \\
& $(0.180)$ & $(0.768)$ & $(0.930)$ \\
Constant & $\left(1.60^{* * *}\right.$ & & \\
& $(0.324)$ & & \\
& & & 90 \\
Observations & 102 & 90 & -1.017 \\
R-squared & 0.711 & -0.539 & 6 \\
Number of countries & 6 & 6 & 0.507 \\
Sargan(p-value) & & 0.478 & \\
\hline
\end{tabular}

Source: Author's using Statat 13

Note: Robust standard errors are reported in brackets. (***, **, *) indicate statistically significance at $1 \%, 5 \%$ and $10 \%$.

As with the above alternative measures of natural resources, forest rent has a negative and significant effect on the $\log$ gross domestic product. Likewise, education has a positive and significant as does the interaction 3 variable (education * Forest_rent). But, the education rate is not robust; because it loses its significance by the regression with the 2 SLS and the LIML. The education rate which contributes to the transmission of the negative effects of forest rent on economic development is $61.3 \%$ by my fixed-effects method, 48.98 by the 2SLS method and 48.90 by the LIML.

On the other hand, investment and government spending lose their signs and significance, unlike when we measure the abundance of natural resources by the total resource rent and the oil rent.

However, the variable capturing freedom and responsibility in CEMAC (voice) and employment (employee) retain their signs and remain significant.

\section{Conclusion}

On the one hand, it was a question of determining the effect of the abundance of natural resources on the economic development of the CEMAC countries; and on the other hand, to analyze the role of human capital in the transmission of these effects. Natural resources are essential for human survival. Several states have used their wealth in natural resources to increase their levels of development. This is the case with the United States of America, Great Britain and Canada, during the industrial revolution in the 18th and 19th centuries. However, recent studies show that the exploitation of natural resources can be seen as a double-edged sword because it provides important financial resources for economic development; but, it also weakens the economies of the countries that depend on it. The work of Sachs and Warner (1995, 1999, and 2001) has shown that the exploitation of natural resources reduces the growth of countries that are dependent on them. Otherwise, states dependent on the exploitation of natural resources are less developed than diverse states. Likewise, Gylfason (2001) shows that the exploitation of natural resources negatively affects human capital. Ghamsi et al. (2020) have shown that in CEMAC, mineral resources (minerals and oil) have negative effects on human capital. Likewise, this present study shows us that the abundance of NRs harm economic development. The Exploitation of natural resources limits growth as long as the level of human capital is low Bravo-Ortega and De Gregorio (2005). According to Zallé (2018), countries must simultaneously step up their investments in human capital to turn the natural resource curse into a blessing. Our study shows us that education contributes to the transmission of the negative effects of natural resources on economic development. In fact, for better management of natural resources a high level of education is needed. However, in CEMAC the enrollment rate is very low. Education enables the local population to participate actively in the management of resource income either through local processing of (agricultural and timber resources) or by appointing their representatives to various strata of the state. In most countries of the world, the benefits of education are exhibited, but investment in the education sector is hampered by the lack of financial means in most countries (Shao and Yang, 2014).

\section{Four main recommendations:}

$\checkmark \quad$ The creation of a special "human capital" fund. The financial resources allocated to this fund will come from part of the rent from the natural resources exploited. There would be additional funding for investments in human capital, which could be released at any time the need arises; to increase the supply of education.

$\checkmark \quad$ Strengthen the fight against child labor. Two measures can be adopted: first, sensitize parents to send their children to school. Then, supervise mining activities with the same objective. 
$\checkmark$ Governments will also be able to extend the duration of compulsory education. That said, make compulsory from primary to lower secondary education or compulsory education up to 18-20 years, depending on the demographic development of each country.

$\checkmark$ The accessibility of education in urban and rural areas in the countries of the CEMAC zone remains very unequal. To this end, we recommend the public authorities to provide rural areas with infrastructure and to improve the teachers who work there.

\section{References}

Acemoglu D., Johnson S. \& Robinson J. A. (2001), « The Colonial Origins of Comparative Development: An Empirical Investigation », The American Economic Review, Vol. 91, No 5, pp 1369-1401.

Aghion P. \& Howitt P. (1998), «Endogenes Growth Theory », MIT Press, Cambridge (trad. française: théorie de la croissance endogène, Dunod, 2000.

Alexeev M. and Conrad R. (2009), "The elusive curse of oil” Review of Economics and Statistics, vol.91, n 3, pp. 586-98.

Aoun M. C. (2008), «La rente pétrolière et le développement économique des pays exportateur », Université paris dauphine edocif. Sciences des Organisations CGEMP - Centre de Géopolitique de l'énergie et des Matières Premières.

Atangana O. H (2019), « Natural resource curse: A reality in Africa », Resources Policy, vol 63.

Auty R. (1993), « Sustaining Development in Mineral Economies: The Resource Curse Thesis», London: Routledge.

Avom D. \& Carmignani F. (2009), "Is mother nature a curse for social development." Macroeconomic research group discussion paper 27 .

BAD (2009), «Effet de la crise financière sur l'Afrique »

Behbudi D., Mamipour S. \& Karam A. (2010), « Natural resource abundance, human capital and economic growth in the petroleum exporting countries », Journal of Economic Development vol 35, nº 3 .

Birdsall N., Pinckney T. \& Sabot R. (2001), « Natural Resources, Human Capital, and Growth », in R. Auty, ed., Resource Abundance and Economic Growth, New York NY, Oxford University Press, pp 57-75.

Boyce J. R. and Herbert J. C. (2011) "Is a negative correlation between resource abundance and growth sufficient evidence that there is a resource curse? Resources Policy, vol. 36, $\mathrm{n}^{\circ}$ 1, pp. 1-13.

Bravo-Ortega C. \& De Gregorio J. (2005) « The Relative Richness of the Poor? Natural Resources, Human capital, and Economic Growth » World Bank Policy Research, Working Paper N 3484.

Brunnschweiler C. \& Bulte E. (2008), « The resource curse revisited and revised: a tale of paradoxes and red herings », Journal of Environmental Economics and Management, vol55, $\mathrm{n}^{\circ} 3$ pp 248-264.

Brunnschweiler C. (2008), « Cursing the Blessings? Natural Resource Abundance, Institutions, and Economic Growth » World Development Vol. 36, No. 3, pp 399-419.

Carbonnier G. (2007), "Comment conjurer la malédiction des ressources naturelles? "Annuaire suisse de politique de développement vol $26, \mathrm{n}^{\circ} \mathrm{C}$

Carbonnier G. (2013), "La malédiction des ressources naturelles et ses antidotes " Revue internationale et stratégique vol 3 , $n^{\circ} 91$

Cavalcanti T.V.D.V., Mohaddes K. and Raissi M. (2011), "Growth, development and natural resources: new evidence using a heterogeneous panel analysis, Review Economy and Finance, vol. 51, nº 4, pp.305-318.

Corden W. M. \& Neary J. P. (1982), « Booming sector and Deindustrialization in a small economy », The Economic Journal vol 92(368), pp 825-848.

Corden W. M. (1984), «Booming sector and Dutch Disease Economics: Survey and Consolidation », Oxford Economic Papers 36(1), pp359-380.

Coulibaly I. (2013), «Long term economic impact of the natural resources and human capital on the growth rate », Research Papers. Paper 399.

Davis G. A. (1995), «Learning to love the Dutch disease: Evidence from the mineral economies », World Development, 23(10), pp1765-1779

DGRIS, (2015), « Impact de la baisse du prix du pétrole sur les pays producteurs d'Afrique équatoriale (Cameroun, CongoBrazzaville, Gabon et Guinée équatoriale) », note ${ }^{\circ}{ }^{23}$

Dione L. A. (2016), «Composition des dépenses publiques et impacts sur la croissance économique : analyses théoriques et empiriques sur des panels de pays développés, émergents et en voie de développement », Université de Bourgogne, Français.

Gelb Alan, (2010) "Diversification de l'économie des pays riches en ressources naturelles "Center for Global Development, Contribution préparée pour le séminaire de haut niveau du FMI Ressources naturelles, finance et développement, Alger, 4-5 novembre 2010

Ghamsi D. \& Tadadjeu W. (2020), « exploitation des ressources minières et capital humain dans la CEMAC », IRADDAC Working Paper Series $\mathrm{N}^{\circ}$ IWP-03/20

Ghamsi D., Tadadjeu W. \& Mofow N. (2019), «Exploitation of Mineral Resources and Human Capital in CEMAC » journal of economics and Sustainable Development, vol 10, $\mathrm{N}^{\circ} 24$

Gregory R. G. (1976), « Some implications of the growth mineral sector », Australian Journal of the Agricultural Economics 》67, pp 455-470.

Gurgand M. (2000), « Capital humain et croissance : la littérature empirique à un tournant ? », Économie publique/Public economics, $\mathrm{Vol} 2, \mathrm{n}^{\circ} \mathrm{O6}$

Gylfason T. (2001), « Natural resources, education and development », European Economic Review 45, pp 847-859.

Hartwick J. M. (1977), « Intergenerational equity and the Investing of Rents from Exhaustible Resources », The American Economic Review (67), pp 972-974.

Hausmann R. \& Rigobon R. (2003), « An alternative interpretation of the resource curse: theory and policy implications», In Davis J., Ossowski R., et Fedelino A. (eds), "Fiscal Policy Formulation and Implementation in Oil-Producing Countries", IMF, Washington. 
Kim D.H. \& Lin S.C. (2017), «Human Capital and Natural Resource Dependence », Structural Change and Economic Dynamics, voll $1 \mathrm{n}^{\circ} \mathrm{Q}$.

Koutassila P. (1998), « Le syndrome Hollandais : théorie et vérification empirique au Congo et au Cameroun », Documents de travail $\mathrm{n}^{\circ} 24$, Centre d'économie du développement, Université Montesquieu-Bordeaux IV.

Kurtz M. \& Brooks S. M. (2011), « conditioning "the resource curse" globalization human capital and growth in oil rich nation », comparative political studies vol 44, $\mathrm{n}^{\circ} 6 \mathrm{pp} 747-770$.

Lane P. \& Tornell A. (1999), « The Voracity Effect », American Economic Review, vol 89, pp 22- 46.

Lederman D. and Maloney W.F. (2007), "Natural resources: Neither curse nor destiny”, World Bank- free PDF.

Lucas, R. E. (1988). « On the Mechanics of Economic Development », Journal of Monetary Economics vol $22(1)$ pp 3-42.

Mankiw N. G., Romer D. \& Weil D. N. (1992), «A Contribution to the Empirics of Economic Growth », Quarterly Journal of Economics, vol. 107, May, pp 407-437.

Manning A. (2004), « Human Capital as a Transmission Mechanism of the Resource Curse », the Park Place Economist, Vol 7.

Mehlum H., Moene K. \& Torvik R. (2006), « Institutions and the Resource Curse », The Economic Journal, vol 116, pp 1-20.

Nakoumde N. (2007), « Boom pétrolier et risque d'un syndrome hollandais au Tchad : une approche par la modélisation en équilibre général calculable » Sciences de l'Homme et Société, Université d'Auvergne.

Noula A., Ghamsi D. \& Mofow (2020), «Exploitation of Mineral Resources and Economic Growth in CEMAC: The Role of Institutions » International Journal of Business and Economic Sciences Applied Research, vol 13, $\mathrm{N}^{\circ} 2$

Omgba L. D. (2010). " Trois essais sur l'économie politique de la rente pétrolière dans les Etats africains ». Université d'Auvergne - Clermont-Ferrand I.

ONU (2016), «profil pays: RCA »

Papyrakis E. \& Gerlagh R. (2004), «The resource curse hypothesis and its transmission Channels », Journal of Comparative Economics vol 32 pp 181-193

Philippot L. M. (2009), "Rente naturelle et institutions. Les Ressources Naturelles : Une " Malédiction Institutionnelle" halshs-00553629.

UNDP (2018), « indices et indicateurs de développement humain », mise à jour statistique 2018

Romer P. (1986), « Increasing Return and Long-Run Growth », Journal of Political Economy, vol 94, October, n5, pp 10021037.

Sachs J. \& Warner A. (1995), « Natural Resource Abundance and Economic Growth », in G. Meier and J. Rauch (eds.), Leading Issues in Economic Development, Oxford University Press, New York.

Sachs J. \& Warner A. (1997), "Source of slow growth in African economies", journal of African economies, vol. 6 (3), pp 35-76.

Sachs J. \& Warner A. (1999) «The big push, natural resource booms and growth », Journal of Development Economics, vol 59 , pp $43-76$.

Sachs J. \& Warner A. (2001), « Natural Resources and Economic Development The curse of natural resources », European Economic Review, vol 45 p827-838.

Shao S. \& Yang L. (2014), « Natural resource dependence, human capital accumulation, and economic growth: A combined explanation for the resource curse and the resource blessing », Energy Policy 74, pp 632-642.

Shao S. \& Yang L. (2014), « Natural resource dependence, human capital accumulation, and economic growth: A combined explanation for the resource curse and the resource blessing », Energy Policy 74, pp 632-642.

Shaxson N. (2005), " New approaches to volatility: dealing with the "resource curse" in sub-Saharan Africa ", international affair vol 81(2), pp 311-324

Solow R. (1956), «A Contribution to the Theory of Economic Growth », Quarterly Journal of Economics, 70, pp 65-94.

Stijns J. P. (2006), « Natural resource abundance and human capital accumulation », World Development, Vol. 34, No. 6, p. $1060-1083$,

Torvik R, (2002), « Natural resources, rent-seeking and welfare », Journal of Development Economics, vol 67, pp 455-470.

Torvik R, (2009), « Why do some resource-abundant countries succeed while others do not? », Oxford Review of Economic Policy, vol 25(2), pp 241-256.

Van der Ploeg F. \& Ploelhekke S. (2008), « The volatility curse: revisiting the paradox of plenty », DNB working paper $n^{\circ}$ 206.

Van der Ploeg F. \& Ploelhekke S. (2010), « The pungent smell of "red herrings": Subsoil assets, rents volatility and resource curse », Journal of Environmental Economics and Management, forthcoming.

WDI (2018), World Development Indicators, database of development in the word

WGI (2018), Worldwide Governance Indicators, database of governance

Zallé O. (2018), Natural resources and economic growth in Africa: the role of institutional

and human capita », resources policy, vol (62).

quality

This is an Open Access article distributed under the terms of the Creative Commons Attribution Licence

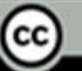


DOI: 10.25103/ijbesar.143.04 